\title{
MAKNA DAN SIMBOL BERENTAK \\ DALAM UPACARA BESALE \\ PADA MASYARAKAT SUKU ANAK DALAM \\ DI DUSUN JOHOR BARU DESA BUNGKU \\ KABUPATEN BATANGHARI JAMBI
}

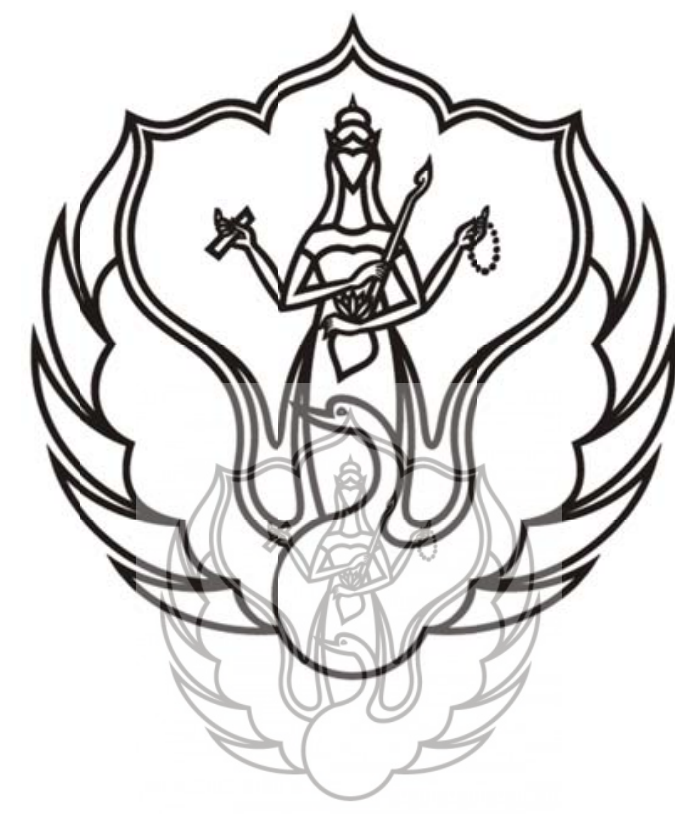

Oleh:

Arini Novriawati NIM: 1211420011

\section{TUGAS AKHIR PROGRAM STUDI SI TARI JURUSAN TARI FAKULTAS SENI PERTUNJUKAN INSTITUT SENI INDONESIA YOGYAKARTA GASAL 2017/2018}


MAKNA DAN SIMBOL BERENTAK

DALAM UPACARA BESALE

PADA MASYARAKAT SUKU ANAK DALAM

DI DUSUN JOHOR BARU DESA BUNGKU

KABUPATEN BATANGHARI JAMBI

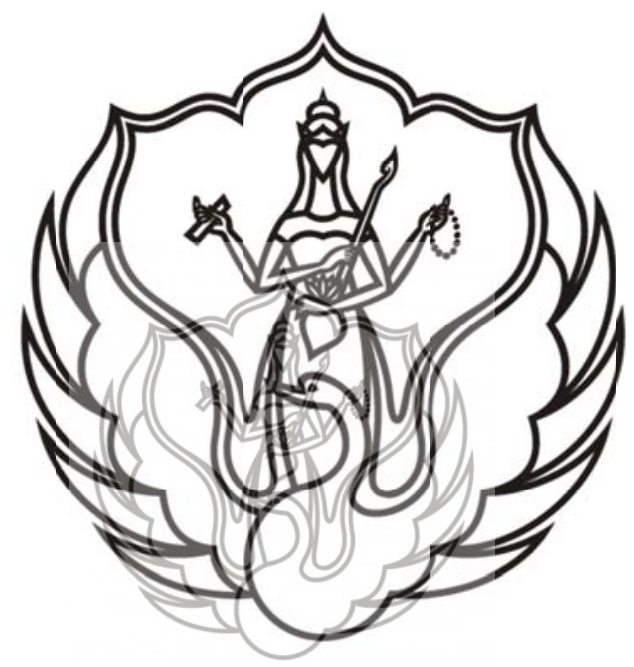

Oleh:

Arini Novriawati

NIM: 1211420011

Tugas Akhir Ini Diajukan Kepada Dewan Penguji

Fakultas Seni Pertunjukan Institut Seni Indonesia Yogyakarta

Sebagai Salah Satu Syarat

Untuk Mengakhiri Jenjang Studi Sarjana S-1

Dalam Bidang Tari

Gasal 2017/2018

\section{UPT Perpustakaan ISI Yogyakarta}


Tugas akhir ini telah diterima

Dan disetujui Dewan Penguji

Fakultas Seni Pertunjukan

Institut Seni Indonesia Yogyakarta

Yogyakarta, 16 Januari 2018

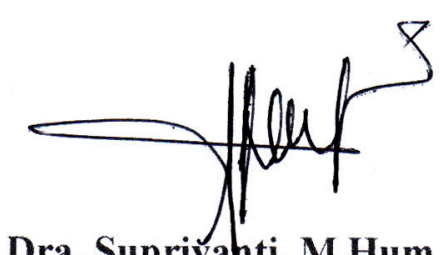

Dra. Suprivahti, M.Hum

Ketua/ Anggota

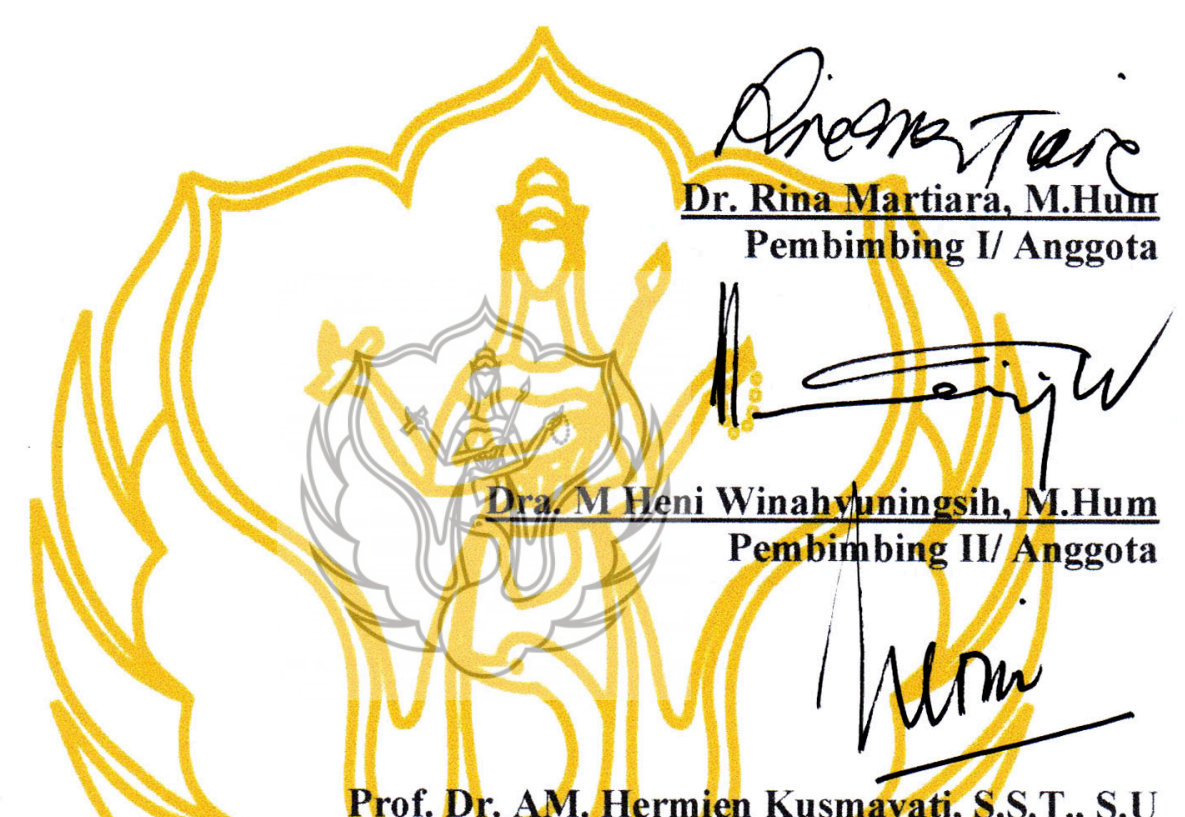

Penguji Ahli/ Anggota

Mengetahui

Dekan Fakuitas Seni Pertunjukan

Institu Aeni Indonesia Yogyakarta

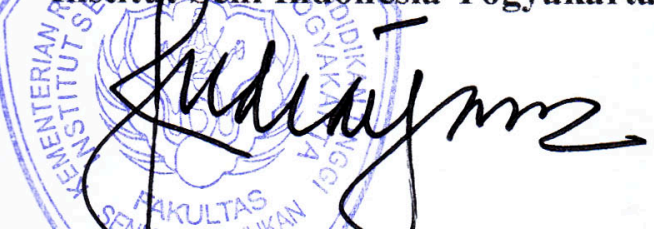

Prof.Dr.Hi Endiarrani, M.A

NIP. 195606301987032001 


\section{PERNYATAAN}

Dengan ini saya menyatakan bahwa dalam skripsi ini tidak terdapat karya yang pernah diajukan untuk memperoleh gelar kesarjanaan di suatu perguruan tinggi, dan sepanjang pengetahuan saya juga tidak terdapat karya atau pendapat yang pernah ditulis atau diterbitkan oleh orang lain, kecuali secara tertulis diacu dalam naskah ini dan disebutkan dalam daftar pustaka.

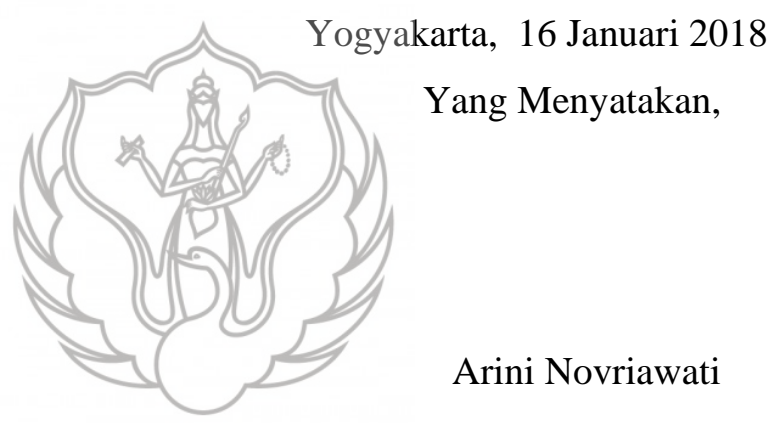

\section{UPT Perpustakaan ISI Yogyakarta}




\section{KATA PENGANTAR}

Segala puji dan syukur penulis panjatkan kehadirat Allah SWT yang telah melimpahkan rahmat dan karunia-Nya, memberi petunjuk dan jalan yang terbaik bagi penulis sehingga penyusunan skripsi yang berjudul "Makna dan Simbol Berentak Dalam Upacara Besale Pada Masyarakat Suku Anak Dalam Di Dusun Johor Baru Desa Bungku, Kabupaten Batanghari, Jambi” dapat terselesaikan dengan baik. Tugas akhir ini merupakan persyaratan guna memperoleh gelar Sarjana seni dengan minat utama Pengkajian Tari Fakultas Seni Pertunjukan Institut Seni Indonesia Yogyakarta.

Penulis sangat menyadari bahwa skripi ini tidak dapat terselesaikan tanpa bantuan dari beberapa pihak, yang telâh memberikan bantuan dan jalan keluar terbaik berupa material maupun spiritual yang sangat membantu penulis dalam penyelesaian Tugas Akhir ini. Pada kesempatan ini penulis ingin mengucapkan terima kasih yang sebesar-besarnya kepada:

1. Ibu Dr. Rina Martiara, M.Hum sebagai dosen pembimbing I yang bersedia membimbing, memberikan pengarahan, serta bersabar dan memotivasi penulis untuk terus berusaha, serta selalu memberikan perhatian dan saran mulai dari awal sampai terlaksananya Tugas Akhir ini.

2. Ibu Dra. M Heni Winahyuningsih, M.Hum sebagai dosen pembimbing II. Beliau yang telah sabar dengan telaten meluangkan waktu untuk membimbing, memberi masukan dan arahan selama proses penulisan skripsi ini.

\section{UPT Perpustakaan ISI Yogyakarta}


3. Narasumber berentak pada upacara besale Datuk Usup Beking, Datuk Jahari selaku dukun Sale Di Dusun Johor Baru, Ibu Nurma sebagai inang, Bapak Kotip sebagai biduan, Bapak Abas, Bapak Bokir, serta Bapak Utut Adianto selaku kepala desa Bungku, yang telah membantu penulis dalam memberi informasi dan pengalaman yang berharga ini.

4. Bapak Dindin Heryadi, M.Sn sebagai Sekretaris Jurusan dan dosen pembimbing studi penulis yang memberi asuhan dengan kesabaran dan membimbing dari awal perkuliahan hingga dapat menyelesaikan studi pada program S-1.

5. Dra. Supriyanti, M.Hum Ketua Jurusan Tari Institus Seni Indonesia Yogyakarta, terima kasih atas bantuan, masukan, dan petunjuk bagi kelancaran penulisan skripsi ini.

6. Pengurus dan Karyawan berbagai peepustakaan, diantaranya: ISI Yogyakarta, Badan Perpustakaan dan Arsip Daerah Istimewa Yogyakarta,

7. Bapak/Ibu Dosen Jurusan Tari ISI Yogyakarta yang telah mendidik dan memberikan semua ilmu yang berharga selama ini.

8. Teruntuk kedua orang tua Bapak Boneh dan Almarhumah ibu Kasnil tercinta yang telah memberikan kasih sayang, panutan, dukungan serta doa untuk terus memberikan semangat kepada penulis selama menempuh pendidikan dan kepercayaan yang teramat besar sampai saat ini. Kepada Kakak Julinda Sari, S.pd, Abang Julianto, dan Nurazizah saudara tercinta yang selama ini memberikan doa, motivasi, kasih sayang dan dukungan yang teramat besar kepada penulis hingga tercapainya penulisan ini.

\section{UPT Perpustakaan ISI Yogyakarta}


9. Kepada keluarga besar Sanggar Selaras Sekato, Bapak Robi, Ibu Ulfa, Busu Hafiz, Abang Iwan, Abang Afriyaldi, Abang Akbar, Kakak Riza, Kakak Putri, Kakak Sari, Senpai Afif dan seluruh keluarga Sanggar yang tidak dapat penulis sebutkan satu persatu dalam dukungannya selama ini kepada penulis.

10. Kepada Trijulina Ria, Putri Any Zairiah, Tiara Fadila, Puja Yanti, Nde Wila, Ristra Safarina A.S, Cicilia Vinny, Enggar Trisnawati, Julistia Pido, Titin Sumanti, kepada seluruh keluarga "sese Production 2012” dan semua pihak yang telah membantu dan mendukung dalam pengerjaan tugas akhir ini, yang tidak dapat disebutkan satu persatu.

\begin{abstract}
Tidak ada kata lain yang dapat penttis ucapkan kecuali ucapan terima kasih, semoga amal baik yang telah diberikan kepada penulis senantiasa mendapat balasan yang layak oleh Allah SWT. Skripsiani masib jauh dari kata sempurna dan banyak hal yang harus diperbaiki. Saran, kritik dan masukan sangat dibutuhkan demi meningkatkan kualitas dari penelitian ini agar lebih baik di kemudian hari. Semoga skripsi ini dapat bermanfaat bagi semua yang membaca
\end{abstract}

Yogyakarta, 16 Januari 2018

Penulis

\title{
Arini Novriawati
}

\section{UPT Perpustakaan ISI Yogyakarta}




\section{MAKNA DAN SIMBOL BERENTAK DALAM UPACARA BESALE PADA MASYARAKAT SUKU ANAK DALAM DI DUSUN JOHOR BARU DESA BUNGKU, KABUPATEN BATANGHARI JAMBI}

Oleh:

Arini Novriawati

NIM: 1211420011

\section{RINGKASAN}

Tulisan ini mengupas "Makna dan Simbol Berentak Dalam Upacara Besale Pada Masyarakat Suku Anak Dalam di Dusun Johor Baru Desa Bungku Kabupaten Batanghari Jambi”. Berentak adalah tari yang dilakukan oleh dukun untuk berkomunikasi kepada Hyang dalam upacara besale. Besale dilakukan oleh Suku Anak Dalam Batin 9 untuk mengobati penyakit yang berasal dari gangguan roh halus. Tari dan semua aspek pendukung pada upacara besale mewakili sebagai tanda yang bertujuan untuk mengetahui makna dan simbol dalam upacara besale sebagai identitas dari masyarakat Suku Anak Dalam Batin 9.

Untuk memecahkan permasalahan penelitian ini, menggunakan pendekatan tentang tanda. Salah satu pendekatan tanda yang dipelopori oleh Ferdinand De Saussure. Saussure melihat tanda dari sudut pandang bahasa. Tanda disusun oleh dua elemen, yaitu penanda (signified), aspek citra tentang bunyi (semacam kata atau representasi visual), dan petanda (signifier) suatu konsep tempat citra-bunyi itu disandarkan. Penelitian ini menganalogikan gerak sebagai media ungkap seperti penggunaan bahasa pada suku tertentu. Hal ini juga tampak pada berentak sebagai sebuah tanda, dimana gerak sebagai penanda dan besale sebagai petanda. Bahasa tersebut setara dengan keseluruhan pertunjukan besale. Tanda yang hadir dalam sebuah pertunjukan seperti, tari, pelaku, properti, iringan, kostum, tempat dan waktu pelaksanaan menjadi aspek saling terkait satu sama lain sehingga sebuah tanda yang dimaknai dapat terpecahkan.

Simbol yang terdapat pada upacara besale tampak pada pelaku, tari, properti, iringan, kostum, waktu dan tempat pelaksanaan yang saling mendukung satu sama lain sebagai penggambaran Suku Anak Dalam Batin 9 dalam menjalankan adatistiadat mereka. Dikarenakan adanya pengaruh dari kepercayaan Animisme pada masa lampau. Hal tersebut mempengaruhi masyarakat ketika malapetaka datang dalam bentuk penyakit, mereka akan mengadakan upacara besale. Makna yang terkandung pada upacara besale ialah gambaran dari perjuangan, ketulusan dan tanggung jawab masyarakat sebagai bentuk permohonan maaf dan memohon dalam keselamatan agar terhindar dari malapetaka.

Kata Kunci: Berentak, Upacara Besale, Suku Anak Dalam Batin 9

\section{UPT Perpustakaan ISI Yogyakarta}




\section{DAFTAR ISI}

Halaman Judul $\ldots \ldots \ldots \ldots \ldots \ldots \ldots \ldots \ldots \ldots \ldots \ldots \ldots \ldots \ldots \ldots \ldots$

Halaman Pengesahan . .................... ii

Halaman Pernyataan..$\ldots \ldots \ldots \ldots \ldots \ldots \ldots \ldots \ldots \ldots \ldots \ldots$ iii

Kata Pengantar $\ldots \ldots \ldots \ldots \ldots \ldots \ldots \ldots \ldots \ldots \ldots \ldots \ldots \ldots \ldots \ldots \ldots$ iv

Halaman Ringkasan . . . . . . . . . $\ldots \ldots \ldots \ldots \ldots \ldots \ldots$ vii

Daftar Isi $\ldots \ldots \ldots \ldots \ldots \ldots \ldots \ldots \ldots \ldots \ldots \ldots \ldots \ldots \ldots \ldots \ldots \ldots \ldots \ldots$

Daftar Gambar ............................ xii

\section{BAB I PENDAHULUAN}

A. Latar Belakang Masafah . A............... 1

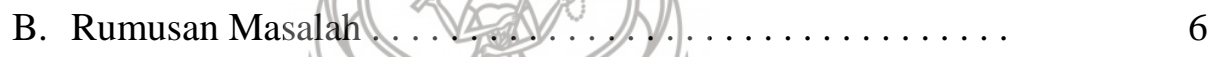

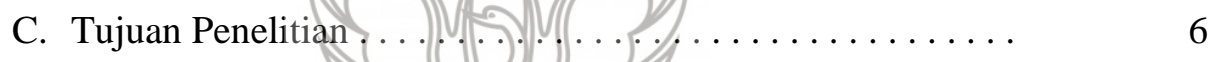

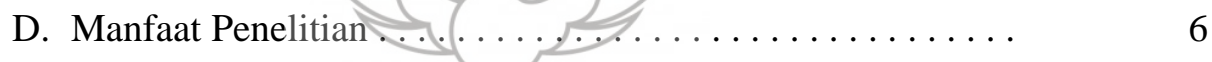

E. Tinjauan Pustaka $\ldots \ldots \ldots \ldots \ldots \ldots \ldots \ldots \ldots \ldots \ldots \ldots$

F. Pendekatan Penelitian . . . . . . . . . . . 10

G. Metode Penelitian .................... 13

1. Tahap Pengumpulan Data ............... 13

a. Studi Pustaka ..................... 13

b. Observasi ...................... 14

c. wawancara .................. 15

d. dokumentasi ..................... 15

2. Tahap Analisis Data ................. 16

3. Tahap Penulisan Akhir ................. 16

\section{UPT Perpustakaan ISI Yogyakarta}


BAB II KONDISI SOSIAL BUDAYA SUKU ANAK DALAM DI DESA BUNGKU KABUPATEN BATANGHARI

A. Keadaan Geografi. ....................... 18

B. Sejarah Suku Anak Dalam Desa Bungku. .............. 21

C. Pola Hidup Masyarakat Suku Anak Dalam. ............ 25

1. Tempat Tinggal $\ldots \ldots \ldots \ldots \ldots \ldots \ldots \ldots \ldots \ldots \ldots$

2. Mata Pencaharian $\ldots \ldots \ldots \ldots \ldots \ldots \ldots \ldots \ldots \ldots \ldots \ldots$

a. Berkebun atau Berladang . . . . . . . . . . . 28

b. Berburu dan Mencari Ikan . . . . . . . . . . . . . 29

c. Ngambek/Repoh DiBatang Sialang ............ 30

D. Sistem Religi Di Desa Bungku f............ 32

E. Sistem Sosial Masyarakat Ulu dan Masyarakat Ilir di Provinsi Jambi. . 33

F. Sistem Kekerabatan ................. 36

G. Adat Istiadat $\ldots \ldots \ldots \ldots \ldots \ldots \ldots \ldots \ldots \ldots \ldots \ldots$

1. Etika Dan Sopan Satun. . . . . . . 38

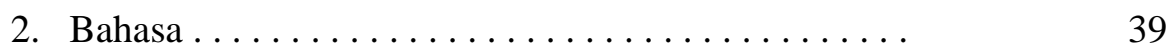

3. Siklus Kehidupan. ................. 41

a. Upacara Kelahiran . . . . . . . . . . . . . . 41

b. Upacara Perkawinan ............... 42

c. Kematian .................. 43

H. Sistem Kepemimpinan . . . . . . . . . . 43

I. Konsepsi Hidup Masyarakat Suku Anak Dalam ....... 45 
BAB III BERENTAK DALAM UPACARA BESALE

A. Pengertian Upacara Besale. ............... 48

B. Pelaku Upacara Besale. . . . . . . . . . . . . . . . . . . .

C. Perlengkapan Dalam Upacara Besale. . . . . . . . . . . . 55

D. Persiapan Upacara Besale. . . . . . . . . . . . . . . 57

E. Berentak Sebagai Puncak Upacara Besale ........... . 64

F. Akhir Pertunjukan Besale . . . . . . . . . . . . . . .

G. Kostum Sidi ....................... 75

H. Iringan Musik dan Syair Dalam Berentak. . . . . . . . . . 77

I. Tempat Pelaksanaan Besale................. 81

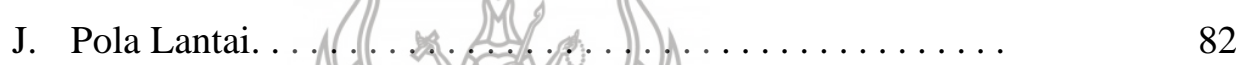

BAB IV MAKNA DAN SIMBOL BERENTAK DALAM UPACARA BESALE

A. Makna dan Simbol Berentak................. 88

B. Makna dan Simbol Gerak Berentak. . . . . . . . . . . . . 90

C. Makna dan Simbol Iringan dan Syair Pada Berentak. ...... . 101

D. Makna dan Simbol Rias Busana Berentak

Pada Upacara Besale ....................... 105

E. Makna dan Simbol Properti Berentak Pada

Upacara Besale. ........................ 106

F. Makna dan Simbol Pola Lantai Berentak

Pada Upacara Besale. . . . . . . . . . . . . . . . . . . . . . . 109

G. Makna dan Simbol Tempat dan Waktu Pelaksanaan

Berentak Pada Upacara Besale . . . . . . . . . . . . . . .

\section{UPT Perpustakaan ISI Yogyakarta}




\section{DAFTAR SUMBER ACUAN}

A. Sumber Tercetak ..................... 114

B. Narasumber ..................... 116

C. Videografi ....................... 117

D. Webtografi ..................... 117

LAMPIRAN $\ldots \ldots \ldots \ldots \ldots \ldots \ldots \ldots \ldots \ldots \ldots \ldots \ldots \ldots \ldots \ldots \ldots$

GLOSARIUM ................................ 120

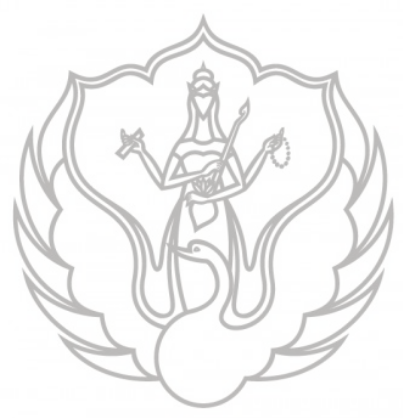




\section{DAFTAR GAMBAR}

Gambar 1 : Bentuk dari balai-balaian

Gambar 2 : Balai ancak kembang sebelum dihias

Gambar 3 : Balai ancak kembang setelah dihias

Gambar 4 : Balai pengasuh

Gambar 5 : Isi dari ancak kuning

Gambar 6 : Inang menyiapkan takir sebelum disusun di dalam balai-balai

Gambar 7 :Lilin madu

Gambar 8 : Selundang mayangyang digunakan sebagai properti saatBerentak

Gambar 9 :Sikap awal Sidi sebelum Berentak dengan memegang properti berupa selundang mayang,Bujang pembayu berada dibelakang Sidi

Gambar 10 : Sikap hentakan kaki Sidi ketika Berentak dan Bujang pembayu yang memegang Sidi daribelakang

Gambar 11 : Sikap Sidi yang merentangkan/kedua tangan setelah memberikan Selundang mayang kepada Sidipengganti

Gambar 12 : Sidi pengganti menghirup asap kemenyan yang diberikan oleh Inang

Gambar 13 : Sikap kuda-kuda pada tumpuan kaki Sidi sambil memegang selundang mayang pada tangan kiri dan tangan kanan pada posisi penghadap kedepan

Gambar 14 : Pakaian yang digunakan Sidi saat Besale

Gambar 15 : Sidi menggunakan hiasan sumping

Gambar 16 : Instrument redap

Gambar 17 : Denah rumah yang digunakan sebagai tempat upacara Besale

Gambar 18 : Posisi ancak karaman, mayang pinang, pare gawar yang berada di sudut rumah

Gambar 19 : Pola lantai 1 dilalui oleh Sidi dan Sidi pendamping, membentuk lingkaran.

Gambar 20 : Pola lantai 2 Sidi utama dan Sidi pendamping Berentak lurus ke arah pintu untuk membuang bertih

\section{UPT Perpustakaan ISI Yogyakarta}


Gambar 21 : Pola lantai 3 dilihat dari atas Sidi bergerak maju dan mudur, kemudian melanjutkan kembali lintasan melingkar.

Gambar 22 : Sidi di asapi kemenyan.

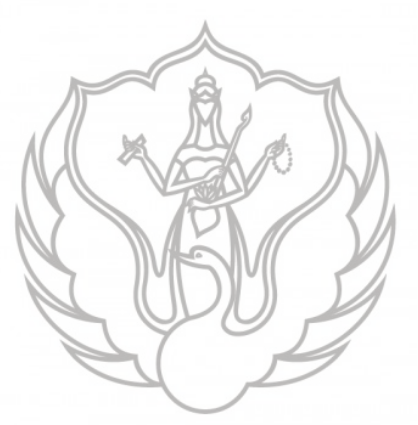




\section{BAB I}

\section{PENDAHULUAN}

\section{A. Latar Belakang Masalah}

Suku Anak Dalam (SAD) adalah salah satu keturunan penduduk asli yang berada di Jambi. Para ahli antropologi membedakan ras Melayu atas dua bagian, yaitu Melayu Muda (Deutro) dan Melayu Tua (Proto). ${ }^{1}$ Keturunan yang masuk ke dalam Melayu Tua seperti Suku Anak Dalam, Suku Bajau, Suku Kerinci, dan Suku Batin. Persebaran Suku Anak Dalam tinggal dan hidup di 9 anak sungai, 5 anak sungai di antaranya berada di daerah Kabupaten Batanghari.

Kabupaten Batanghari merupakan daerah persebaran terbesar Suku Anak Dalam, dikenal dengan sebutan batin 9. Penyebutan ini dikarenakan Suku Anak Dalam hidup dan tersebar di 9 anak sungai, antara lain sungai Bulian, Jangga, Jebak, Bahar, Pemusiran, Burung Antu, Telisak, Sekamis dan Singoan. ${ }^{2}$ Pada masa lalu masyarakat Suku Anak Dalam hidup jauh di dalam hutan. Untuk bertahan hidup mereka bergantung kepada alam dengan cara berburu dan bertani. Dengan ditertibkannya masyarakat terpencil untuk tinggal menetap di bawah naungan desa, membuat Suku Anak Dalam tinggal dan bermukim di desa-desa. Pada saat yang sama

\footnotetext{
${ }^{1}$ Bambang Suwondo, 1978, Adat Istiadat Daerah Jambi, Jambi: Proyek Penelitian dan Pencatatan Kebudayaan Daerah Departemen Pendidikan dan Kebudayaan, p. 27.

${ }^{2}$ Wawancara dengan bapak Utut, pada tanggal 17 Juli 2017, di Desa Bungku Kab.Batanghari.
}

\section{UPT Perpustakaan ISI Yogyakarta}


beberapa suku pendatang mulai menetap di daerah Kabupaten Batanghari seperti suku Melayu, suku Minang, suku Jawa, suku Batak, suku Bugis, suku Banjar, dan lain-lain. Salah satu daerah tempat mereka tinggal adalah Dusun Johor Baru, Desa Bungku, Kecamatan Bajubang Kabupaten Batanghari. Daerah ini termasuk daerah yang ramai penduduk baik dari pendatang maupun penduduk asli, dan Suku Anak Dalam mulai hidup berdampingan dengan masyarakat pendatang yang menyebabkan terjadinya akulturasi.

Akulturasi adalah suatu proses belajar unsur-unsur kebudayaan asing oleh suatu warga masyarakat, yang kemudian lambat laun kebudayaan asing tersebut terolah ke dalam kebudayaan asli. ${ }^{3}$ Dari proses akulturasi ini hampir sebagian besar Suku Anak Dalam telah beragama Islam.Meskipun demikian pola kehidupan yang masih bergantung kepada alam membuat masyarakat Suku Anak Dalam tidak dapat meninggalkan kebiasaan mereka dalam béberapa kegiatan ritual, salah satunya adalah upacara besale.

Upacara besale adalah upacara tradisional yang dipercaya memiliki unsur magis (mistis) untuk mengobati orang yang sakit. Masyarakat yang hidup di dalam hutan tentu sulit untuk menjangkau pengobatan dengan memakai jasa medis, sehingga upaya pengobatan umumnya masih dilakukan melalui upacara-upacara ritual. Besale secara harfiah diartikan sebagai “duduk bersama-sama, memohon pada yang Maha Kuasa agar diberikan kesehatan, ketentraman, dan dihindarkan dari

\footnotetext{
${ }^{3}$ Sumaryono, 2011, Antropologi Tari: Dalam Prespektif Indonesia, Yogyakarta: Badan Penerbit ISI Yogyakarta, p. 23
}

\section{UPT Perpustakaan ISI Yogyakarta}


marabahaya”. ${ }^{4}$ Akan tetapi menurut masyarakat setempat, berdasarkan sejarah dan asal usulnya besale diartikan sebagai be-soleh atau saleh dan penyebutan saat ini menjadi besale. ${ }^{5}$ Arti kata saleh, tentu tidak dapat disepadankan dengan pemahaman Islam, karena pada masyarakat Suku Anak Dalam masih adanya perpaduan antara paham Animisme-Dinamisme sehingga upacara ini masih kental akan kepercayaan atas roh nenek moyang.

Upacara besale dipimpin oleh seorang dukun yang disebut dengan sidi. Sidi dipercaya memiliki kemampuan khusus yang tidak dimiliki oleh sembarang orang untuk memimpin upacara besale. Upacara ini biasanya dilaksanakan pada malam hari hingga pagi menjelang, dan tempat pelaksanaan di dalam ruangan ataupun di dalam rumah.

Pada upacara besale, sidi dibantuleh inang, biduan, dan bujang pembayu. inang bertugas untuk berkomunikasi kepada Hyang ketika sidi dalam keadaan trance atau kerasukan. Inang membantu mempersiapkan semua keperluan yang dibutuhkan oleh sidi, selain itu inang juga membantu menyadarkan kembali sidi dari keadaan trance. bujang pembayu adalah orang yang mengikuti langkah Sidi saat menari, ia bertugas untuk mengarahkan sidi bergerak. Hal ini dikarenakan ketika dalam keadaan trance, sidi akan kesulitan untuk terus menari sambil bergerak mengelilingi balai dan mengelilingi orang yang sakit. Biduan adalah orang yang bertugas memainkan redap sebagai alat musik pengiring dalam besale.

${ }^{4}$ RianHidayat, 2012, Membangkitkan Batang Terendam:Sejarah Asal Usul Kebudayaan dan Perjuangan Hak SAD Batin 9, Jambi: Yayasan SETARA Jambi, p. 75

${ }^{5}$ Dikutip dari video Besale dokumentasi oleh Dinas Pariwisata provinsi Jambi tahun 2010.

\section{UPT Perpustakaan ISI Yogyakarta}


Pada masyarakat primitif ritual keagamaan umumnya masih terkait erat dengan seni pertunjukan, dan tari hadir di dalamnya. Sejarah peradaban manusia menunjukkan jejak aktivitas manusia yang berkaitan dengan ritual. ${ }^{6}$ Pada masyarakat Suku Anak Dalam ritual pengobatan besale sebagai contoh eksistensi sebuah kebudayaan yang tidak tergerus oleh zaman modernisasi. Tari yang berkaitan erat dengan upacara ini memiliki makna dan simbol sebagai identitas dari masyarakat Suku Anak Dalam Batin 9. Beberapa pendapat dan teori tentang makna dan simbol, di antaranya dipelopori oleh Ferdinand de Saussure dan Charles Sanders Pierce. Saussure dengan konsep penanda-petanda bersifat abritrer (bebas), sementara Pierce hubungan antara penanda (icon) dan petanda (indeks) bersifat alamiah atau memiliki motif. $^{7}$

Besale dan tari tidak dapat dipisahkan-dalam upacara ini. Konsep masyarakat yang memahami bahwa tidak ada perbedaan antara upacara dan tari sehingga Besale dapat dipahami sebagai sebuah bentuk seni pertunjukan yang didalamnya terdapat tari, musik, syair, properti, kostum, dan tempat pertunjukan. Berentak adalah tarian yang dilakukan oleh sidi dalam keadaan trance saat besale berlangsung. Tujuan dari berentak dan menyanyikan syair adalah untuk memanggil roh para leluhur untuk hadir dalam upacara besale ${ }^{8}$. Tari yang dilakukan oleh sidi dominan pada gerak kaki, ia bergerak dengan hentakan kaki sambil meloncat maju dan mundur. Sidi akan

\footnotetext{
${ }^{6}$ Yanti Heriyawati, 2016, Seni Pertunjukan dan Ritual, Yogyakarta: Penerbit Ombak, p. 1.

${ }^{7}$ Arthur Asa Berger, 2010, Pengantar Semiotika: Tanda-Tanda dalam Kebudayaan Kontemporer, terj. M dwi Maranto, Yogyakarta: Tiara Wacana, pp. 13- 25

${ }^{8}$ Wawancara dengan Datuk Jahari pada tanggal 17 Juli 2017di Desa Bungku diizinkan untuk dikutip.
}

\section{UPT Perpustakaan ISI Yogyakarta}


berentak sambil menyanyikan syair yang diiringi oleh tabuhan redap. Redap merupakan alat musik yang menyerupai gendang Melayu, terbuat dari kulit rusa atau kambing. Redap dimainkan selama besale berlangsung. Properti dalam besale adalah balai-balaian, yaitu miniatur rumah yang digunakan untuk menyimpan sesajen. Beberapa jenis balai yang digunakan dalam upacara besale, adalah balai kurung rahasio, balai pengasuh, balai pengadap dan surau. Setiap balai memiliki fungsi yang berbeda-beda. ${ }^{9}$

Tari yang hadir dalam besale adalah sebuah tanda, sebagaimana yang diungkapkan oleh Ferdinand De Saussure di dalam buku Semiotika Komunikasi oleh Alex Sobur yang menjelaskan tentang tanda sebagai berikut:

"Tanda adalah kesatuan dari suatu bentuk penanda (signifier) dengan sebuah idea tau petanda (signified). Penanda adałah "bunyi yang bermakna" atau "coretan yang bermakna”. Jadi, penanda adalah aspek aspek material dari bahasa: apa yang dikatakan atau didengar dan apa yang ditulis atau dibaca. Petanda adalah gambaran mental dari bahasa”. ${ }^{10}$

Tertarik dengan kekuatan tari, syair, properti, musik, kesatuan antara pelaku sebagai satu kesatuan yang saling terkait maka penelitian ini akan menganalisis makna dan simbol berentak pada upacara besale di dusun Johor Baru Kabupaten Batanghari dengan memakai teori Ferdinand De Saussure.

\footnotetext{
${ }^{9}$ Rian Hidayat, p. 76.

${ }^{10}$ Alex Sobur, 2003, Semiotika Komunikasi, Bandung: PT Remaja Rosdakarya, p. 46.
}

\section{UPT Perpustakaan ISI Yogyakarta}




\section{B. Rumusan Masalah}

Berdasarkan latar belakang di atas maka rumusan masalah penelitian adalah:

Apa makna dan simbol Berentak dalam Upacara Besale pada masyarakat Suku Anak Dalam di Dusun Johor Baru Desa Bungku Kabupaten Batanghari ?

\section{Tujuan Penelitian}

Setiap penelitan memiliki tujuan untuk menjawab semua asumsi peneliti terhadap objek penelitiannya. Berangkat dari rumusan masalah yang menghantarkan peneliti untuk fokus mengkaji objek dari salah satu sudut pandang, maka tujuan penelitan ini adalah:

1. Mendeskripsikan berentak dan upacara besale.

2. Menganalisis makna dan simbol berentak pada upacara pengobatan besale oleh Suku Anak Dalam Batin 9 di Dusun Johor Baru Desa Bungku Kabupaten Batanghari.

\section{Manfaat Penelitian}

Ada pun manfaat penelitian adalah sebagai berikut:

1. Menambah pengetahuan tentang kebudayaan Suku Anak Dalam seperti berentak dan upacara besale.

\section{UPT Perpustakaan ISI Yogyakarta}


2. Menambah referensi untuk digunakan meneliti objek yang sama sehingga akan menambah sumber tulisan yang membahas tentang upacara besale Suku Anak Dalam di Kabupaten Batanghari Jambi.

\section{E. Tinjauan Pustaka}

Untuk mengetahui jawaban dari permasalahan diatas, dibutuhkan informasi baik secara tulisan, lisan maupun melalui rekamanvideo. Adapun buku yang digunakan dalam referensi penelitian seperti:

Buku yang ditulis oleh Rian Hidayat, Membangkitkan Batang Terendam:Sejarah Asal Usul Kebudayaan dan Perjuangan Hak SAD Batin 9 (2012). Buku ini memberikan banyak informasi yang belum diketahui oleh peneliti seperti sejarah asal usul Suku Anak Dalam. Perbedaan antara Orang rimba dan Suku Anak Dalam bagaimana masyarakat luar salah dałam membedakan antara Orang rimba, Suku Anak Dalam, dan Orang Kubu. Persebaran masyarakat Suku Anak Dalam dibeberapa wilayah di Batanghari, perjuangan oleh Suku Anak Dalam, dan kebudayaan yang dipegang teguh hingga sekarang seperti upacara besale juga dibahas pada buku ini.

Dari sumber ini dapat diketahui tentang sejarah asal usul Suku Anak Dalam di Batanghari khususnya, persebarannya di sembilan anak sungai, bahkan buku ini menjelaskan pula tentang upacara besale meskipun informasi yang didapatkan antara fakta di lapangan dengan yang tertulis terdapat perbedaan. Namun hal ini justru memperkaya informasi yang dibutuhkan. Buku Membangkitkan Batang Terendam sangat membantu untuk menjelaskan tentang kehidupan masyarakat Suku Anak

\section{UPT Perpustakaan ISI Yogyakarta}


Dalam secara mendalam dan buku ini bisa menjadi buku acuan untuk melanjutkan penelitian upacara Besale.

Naskah yang ditulis oleh Adi Prasetijo dengan judul "Serah Naik Jajah Turun” sebagai Dasar Hubungan Orang Rimba dengan Orang Melayu” pada buku M. Husnul Abid, Seloko: Jurnal Budaya (2012). Buku ini menjelaskan tentang hubungan antara masyarakat ulu dan masayarakat ilir, dimana perbedaan kedua masyarakat ini ialah masyarakat orang rimba dan masyarakat Melayu (Orang Luar) perbedaan kedua suku ini telah tampak sejak zaman kerajaan Melayu adanya pola perbudakan yang dilakukan oleh Orang Melayu membuat mereka (Orang Rimba) takut dan membenci Orang Luar. Pemikiran sepepti ini masih terbentuk antara kedua masyarakat ini hingga sekarang, yang membuat salab/ presepsi/terhadap masyarakat Suku Anak Dalam yang dulunya masih disebut Quang Rimba ditakuti dan dikucilkan.

Buku Arthur Asa Berger terjemahan M. Dwi Marianto, Pengantar Semiotika Tanda-Tanda Dalam Kebudayaan Kontemporer (2010), menjelaskan tentang petanda dan penanda serta makna dan simbol dalam ilmu semiotika dan teori semiologi serta penerapanya pada seni dan budaya pada umumnya. Buku ini membantu untuk mencari sebanyak mungkin penerapan semiotika pada kehidupan sehari-hari agar lebih dipahami petanda-penanda untuk membedah Berentak dan upacara Besale lebih mendalam.

Buku yang ditulis oleh Yanti Heriyawati, Seni Pertunjukan dan Ritual (2016). Buku ini menjelaskan tentang seni pertunjukan dan ritual yang lahir dari masyarakat, berbagai macam pertunjukan ritual yang ada di Indonesia dari bersih desa, ritual

\section{UPT Perpustakaan ISI Yogyakarta}


kesuburan, ritual tolak bala, yang di dalamnya tidak hanya pertunjukan semata, tetapi bisa dilihat bagaimana sebuah seni pertunjukan yang bersifat ritual juga mempresentasikan ciri budaya masyarakat pendukungnya. Dari buku ini dapat dipahami bahwa seni pertunjukan dan ritual berangkat dari sebuah budaya. Masyarakat sebagai sosial kontrol sehingga pertunjukan tersebut masih dapat terus dilaksanakan dimana ritual dianggap penting sebagaimana upacara Besale sebagai identitas dari Suku Anak Dalam di Dusun Johorbaru Desa Bungku Kabupaten Batanghari.

Buku oleh Y. Sumandyo Hadi, Kajian Tari Teks dan Konteks (2007). Menjelaskan sesuai dengan kepercayaan primitif, ekspresi tarian itu kadang kala dilihat dari bentuk geraknya masih sangat sederhana. Sebagian besar didasari dari ungkapan ekspresi manusia yang sering dihubungkan dengan kekuatan alam, kekuatan supranatural, maupun pemujaan atau komunikasi dengan dewa-dewa, serta ritual penyembahan kepada roh nenek moyang. Penjelasan yang ditulis oleh Y. Sumandiyo Hadi menerangkan bahwa tari primitif memiliki gerak yang sederhana. Gerak tari yang terdapat pada upacara Besale sebagai contoh yang memiliki gerak hentakan kaki dan gerakan tangan. Secara menyeluruh buku ini mengkaji tari secara teks dan konteks, pada penelitian ini hal itu sangat dibutuhkan untuk membahas tari pada upacara Besale lebih mendalam.

Buku oleh Kris Budiman, Semiotika Visual Konsep, Isu, dan Problem Ikonisitas (2011). Buku ini menjelaskan secara mendalam tentang konsep semiotika dari dua teori Charles S. Peirce dan Ferdinand de Saussure, sehingga dapat dipahami

\section{UPT Perpustakaan ISI Yogyakarta}


bagaimana cara membedah sebuah objek dengan memakai teori Ferdinand de Saussure. Banyak contoh yang dijelaskan tentang tanda dan penerapannya, buku ini memudahkan penulis untuk mengaplikasikan ke dalam tulisan mengenai berentak pada upacara besale sebagai tanda untuk mencari makna yang terkandung didalamnya.

Buku karya Alex Sobur, Semiotika Komunikasi (2003) menjelaskan tentang tanda melalui teori Ferdinand De Saussure. Secara lugas buku ini membahas satu persatu mengenai penanda (signifier) dan petanda (signified), bentuk (form) dan isi (content), langue dan perole, sinkronis dan diakronis, dan sintagmatik dan paradigmatik. Pada buku ini memaparkan bagaimana Saussure menggunakan bahasa sebagai sebuah tanda yang digunakan pada masyarakat penuturnya sehingga akan tampak berbeda penggunaan satu bałasadengan bahasa lain di tempat yang berbeda. Seperti berentak sebagai tanda, dimana gerak yang dipahami sebagai penanda dan konsep sebuah upacara besale sebagai seni pertunjukan ritual. Penulis dapat membedah objek tari yang dianalogikan dengan bahasa seperti teori yang diungkapkan oleh Saussure.

\section{F. Pendekatan Penelitian}

Pendekatan yang digunakan dalam penelitian ini adalah analisis semiotika Ferdinand De Saussure. Studi sistematis tentang tanda-tanda dikenal sebagai semiologi. Arti harfiahnya ialah "kata-kata mengenai tanda-tanda". Kata semi dalam

\section{UPT Perpustakaan ISI Yogyakarta}


semiologi berasal dari semeion (bahasa Latin), yang artinya 'tanda'. ${ }^{11}$ Pendekatan semiotika berkaitan dengan segala hal yang dapat dimaknai tanda-tanda. Dalam ilmu semiotika dikenal dua teori besar, yaitu teori Charles Sanders Peirce dan teori Ferdinand de Saussure.Teori Peirce tanda (sign atau representamen) selalu dalam hubungan triadik. ${ }^{12}$ Menurut Saussure tanda adalah kesatuan dari suatu bentuk penanda (signifier) dengan sebuah ide atau petanda (signified). ${ }^{13}$ Perbedaan dari kedua teori ini bagi Saussure, tanda-tanda disusun oleh dua elemen yaitu aspek citra tentang bunyi (semacam kata atau representasi visual) dan suatu konsep tempat citrabunyi itu disandarkan, hubungan antara penanda (signifian) dan petanda (signifie) bersifat arbitrer (bebas), namun menurut Peirce hubungan antara indeks dan ikon bersifat alamiah memiliki motif. ${ }^{14}$ Mengkaji objek dengan pendekatan semiotika menemukan sesuatu hal dengan tanda yang hadir dalam sebuah pertunjukan tidak lepas dari aspek tema, gerak tari, ruang, waktu, pendukung, properti yang digunakan, pelaku, iringan, dan rias busana menjadi aspek saling terkait satu sama lain sehingga sebuah tanda yang dimaknai dapat terpecahkan. Arthur Asa Berger dalam bukunya yang berjudul Pengantar Semiotika Tanda-Tanda Dalam Kebudayaan Kontemporer (2010) menyatakan bahwa tanda adalah segala sesuatu yang dapat dilekati atau dimaknai sebagai penggantian yang signifikan untuk sesuatu yang lain.

\footnotetext{
${ }^{11}$ Arthur Asa Berger, 2010, p. 4

${ }^{12}$ Alex Sobur,2009, Semiotika Komunikasi, Bandung: Remaja Rosdakarya, p. 41

${ }^{13}$ Alex Sobur, 2009, p. 46

${ }^{14}$ Arthur Asa Berger, 2010, pp. 13 - 18
}

\section{UPT Perpustakaan ISI Yogyakarta}


Upacara besale menghadirkan sebuah tanda yang mengandung makna mewakili nilai dan norma yang terdapat pada penduduk Suku Anak Dalam batin 9, gerak berentak menjadi simbol gambaran Suku Anak Dalam Batin 9 dalam menjalankan adat-istiadat meraka yang tergambar pada upacara ini. Saussure menggunakan diagram-diagram berikut untuk menggambarkan gagasan-gagasannya.
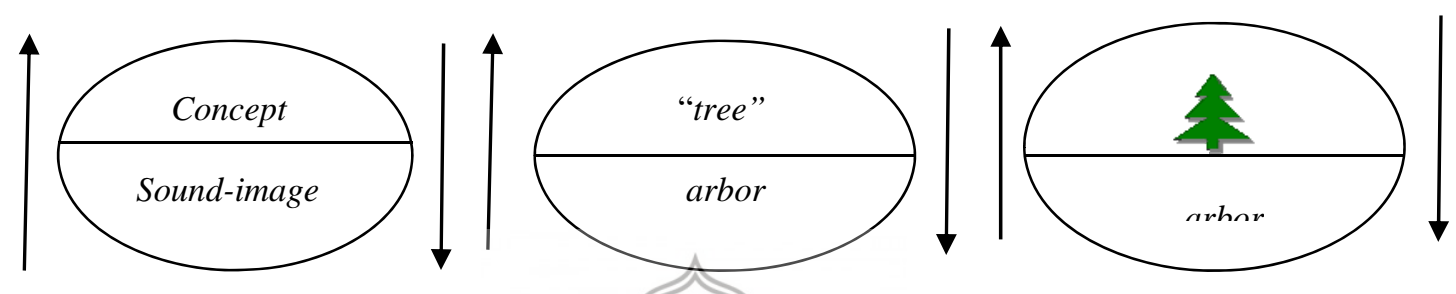

Diagram berikut menggambarkan̂ kesatuan tanda, penanda dan petanda Saussure mengantakan bahwa tandar-tanda itu seperti lembran kertas. Satu sisi adalah penanda dan sisi yang lain menjadi petanda. Kertas itu sendiri adalah tanda.

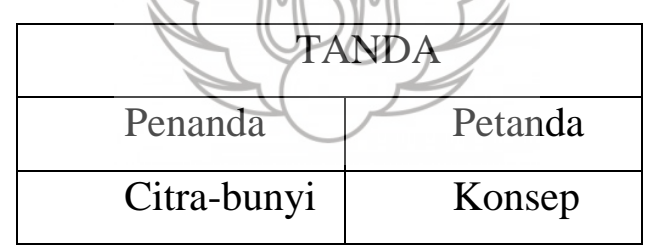

Kita tidak dapat memisahkan penanda dan petanda dari tanda itu sendiri. Penanda dan petanda membentuk tanda. ${ }^{15}$

Untuk mengupas secara mendalam mengenai teks tari Berentak pada Upacara Besale memerlukan dua tahapan antara lain:

- Tahap heuristik (first order semiotics) pengamatan terhadap teks Berentak secara bentuk dan struktural materialnya identifikasi, deskripsi, dan analisis pada upacara besale.

\footnotetext{
${ }^{15}$ Arthur Asa Berger, 2010, p. 14
}

\section{UPT Perpustakaan ISI Yogyakarta}


- Tahap hermeneutik (second order semiotics) pemaknaan teks berentak antara elemen-elemen pendukung yang terdapat pada upacara besale penjelasan secara interpretasi dan intertekstual, keterkaitan antara satu dan lain menjadi satu kesatuan.

\section{G. Metode Penelitian}

Metode penelitian yang digunakan adalah metode kualitatif, penelitian yang dilakukan dengan data kualitatif kemudian dianalisis menggunakan teknik analisis lebih mendalam untuk mengidentifikasi, menentukan presepsi, pendapat, dan gagasan dari beberapa narasumber.

Tahapan yang dilakukan pada penelitian ini antara lain, tahap pengumpulan data, tahap analisis, dan tahap penyusunan laporan.

\section{Tahap Pengumpulan Data}

Tahap pengumpulan data dilakukan untuk memperoleh sumber yang berhubungan dengan objek penelitian. Pengumpulan data dapat dilakukan dengan cara membaca dari sumber referensi tercetak dan tidak tercetak, observasi, dan wawancara. Hal tersebut dapat diuraikan sebagai berikut:

\section{a. Studi Pustaka}

Studi pustaka dilakukan dengan membaca tulisan ilmiah sehingga memperkuat penelitian upacara Besale. Buku yang digunakan adalah buku-buku yang berkaitan dengan upacara pengobatan dari berbagai sumber baik secara langsung maupun

\section{UPT Perpustakaan ISI Yogyakarta}


sebagai buku penunjang sesuai dengan topik permasalahan. Beberapa sumber pustaka diperoleh dari perpustakaan Institut Seni Indonesia Yogyakarta.

\section{b. Observasi}

Observasi merupakan teknik penelitian yang penting untuk mendapatkan data primer dan mencari kebenaran secara objektif sesuai dengan objek penelitian.Penulis mengenal upacara besale melalui garapan tari yang berangkat dari upacara pengobatan oleh Suku Kubu. Melihat upacara ini begitu kental dengan suasana mistis penulis tertarik untuk mengangkat tari ini sebagai sebuah objek penelitian. Ketertarikan ini membawa penulis mencari informasi lebih dalam mengenai asal usul tentang Suku Kubu, dimana secara perlahan penulis mulai mengerti bahwa penyebutan Suku Kubu memiliki makna yang negatif bagi mereka. Membaca dari internet, bertanya dengan wartawan yang memahami tentang Suku Anak Dalam, hingga datang ke tempat pelaksanaan upacara besale di daerah Jebak dan melihat secara langsung pelaksanaan upacara tersebut di tengah masyarakat yang modern seperti saat ini. Penulis melanjutkan penelitian ke Dusun Johor Baru Desa Bungku Kec. Bajubang Kab. Batanghari.

Untuk sampai ke Dusun Johorbaru membutuhkan waktu 2 jam perjalanan menggunakan jalur darat. Jalan yang dilalui adalah jalan yang biasa digunakan kendaraan untuk mengangkut kelapa sawit, sehingga sepanjang perjalanan banyak dijumpai jalan yang berlubang. Hal ini merupakan satu faktor yang menyebabkan sulitnya untuk mendatangi daerah tersebut.

\section{UPT Perpustakaan ISI Yogyakarta}




\section{c. Wawancara}

Wawancara sebagai teknik pengumpulan data yang dapat memperkuat informasi yang diperoleh. Wawancara sebagai proses tanya jawab secara lisan dengan bertemu secara langsung dengan narasumber. Hal ini dilakukan untuk mendapatkan informasi secara akurat. Narasumber dalam penulisan ini adalah pelaku yang masih aktif dalam upacara Besale yaitu:

1. Bapak Utut Adianto sebagai Kepala Desa Bungku

2. Datuk Jahari selaku dukun sale di Dusun Johorbaru.

3. Datuk Abas selaku biduan di Dusun Johorbaru.

4. Datuk Usup Peking selaku dukun sale di Dusun Johorbaru.

5. Ibu Nurma selaku inang di Dusun Johorbaru.

Wawancara dilakukan untuk mendapatkan infomasi mengenai kehidupan masyarakat setempat, tata cara pelaksanaan upacara besale, apa saja yang dibutuhkan dalam upacara besale, siapa saja yang ikut terlibat di dalam upacara besale, dan bagaimana hubungan antara berentak dengan upacara besale. Wawancara ini didokumentasikan dengan perekam suara menggunakan handphone.

\section{d. Dokumentasi}

Dokumentasi dilakukan untuk merekam suatu peristiwa penting selama observasi berlangsung. Pengumpulan data dengan pendokumentasian dibutuhkan untuk memperoleh data sebagai barang bukti dan keabsahan suatu fakta.Data yang diperoleh berupa hasil wawancara dalam bentuk rekaman suara, video prosesi upacara Besale, kostum, alat musik redap, properti yang digunakan dan rumah

\section{UPT Perpustakaan ISI Yogyakarta}


pemukiman warga dalam bentuk foto. Proses pendokumentasian dilakukan di daerah Dusun Johorbaru desa Bungku Kec. Bajubang Batanghari Jambi.

\section{Tahap Analisa Data}

Data yang diperoleh dari hasil wawancara, observasi, dan studi pustaka dikelompokkan sesuai dengan objek permasalahan yang diambil.Data yang mendukung objek penelitian dianalisis menggunakan metode deskriptif analisis, sehingga diperoleh uraian sesuai yang diharapkan, dan diklasifikasikan untuk mendapatkan kerangka penulisan sesuai dengan latar belakang masalah dan tujuan penulisan.

3. Tahap Penulisan Laporan Akhir

Penulisan laporan akhir dari penelitan ini menggunakan jenis deskriptif analisis.Jenis penulisan tersebut digunakan karena penelitian ini bukan sebagai media untuk mendeskripsikan objek saja, melainkan untuk menganalisis apa yang telah terdeskripsikan. Adapun struktur penulisan laporan akhir yang digunakan adalah sebagai berikut:

BAB. I. PENDAHULUAN yang berisi Latar Belakang Masalah, Rumusan Masalah, Tujuan Penelitian, Manfaat Penelitian, Tinjauan Pustaka, Pendekatan Penelitian, dan Metode Penelitian.

BAB II. Menjelaskan tentang Kondisi Sosial Budaya Suku Anak Dalam di Desa Bungku Kabupaten Batanghari, seperti Letak Georafis, Sejarah Suku Anak Dalam,

\section{UPT Perpustakaan ISI Yogyakarta}


Pola Hidup Masyarakat Suku Anak Dalam, Sistem Religi Di Desa Bungku, Sistem Sosial Masyarakat Ulu dan Masyarakat Ilir Di Provinsi Jambi, Sistem Kekerabatan, Adat Istiadat, Sistem Kepemimpinan, Konsepsi Hidup Masyarakat Suku Anak Dalam.

BAB III. Menjelaskan tentang Berentak Dalam Upacara Besale antara lain: Pengertian Upacara Besale, Pelaku Upacara Besale, Perlengkapan Upacara Besale, Persiapan upacara Besale, Puncak Pertunjukan Besale, Tari Berentak, Akhir Pertunjukan Besale, Kostum Sidi, Iringan Musik Dalam Besale, Tempat Pelaksanaan Besale, dan Pola Lantai.

BAB IV. Merupakan hasil analisis tentang Makna dan Simbol Berentak Dalam Upacara Besale meliputi: Gerak Berentak, Iringan dan syair, Rias Busana, Properti, Pola Lantai,Tempat dan Waktu Pełaksanaan Berentak dalam Upacara Besale.

BAB V. Kesimpulan.

\section{UPT Perpustakaan ISI Yogyakarta}

